\title{
HUBUNGAN KELIMPAHAN MEIOFAUNA PADA KERAPATAN LAMUN YANG BERBEDA DI PULAU PANJANG, JEPARA
}

\author{
Dwi Assy, Niniek Widyorini, Ruswahyuni *)
}

Jurusan Perikanan, Fakultas Perikanan dan Ilmu Kelautan, Universitas Diponegoro

J1. Prof. H. Soedharto, SH, Tembalang Semarang. 50275 Telp/Fax (024) 7474698

\begin{abstract}
Abstrak
Lamun merupakan salah satu sumberdaya laut yang sangat potensial dan dapat dimanfaatkan. Organisme benthos seperti meiofauna menepati posisi yang sangat penting dalam proses biodegradasi di ekosistem pantai. Meiofauna bersifat relatif menetap pada dasar perairan. Penelitian ini bertujuan untuk mengetahui kelimpahan meiofauna pada kerapatan lamun yang berbeda di Pantai Pulau Panjang, Jepara dan mengetahui hubungan antara kerapatan lamun yang berbeda dengan kelimpahan meiofauna. Metode pengambilan sampel dan pengamatan meiofauna adalah sampel diambil 7 titik dari setiap stasiun, pengambilan sampel meiofauna dengan menggunakan pralon $20 \mathrm{~cm}$, sampel kemudian disaring dengan menggunakan saringan sampel $0,5 \mathrm{~mm}$ dan diberi formalin sebanyak $4 \%$,larutan rose bengale $^{\mathrm{TM}}$ dan larutan ludox. Jenis lamun yang ditemukan di lokasi penelitian ini didapatkan 5 genera lamun yaitu Thalassia sp, Cymodocea sp, Enhalus sp. Syringodium sp dan Halodule sp. Jumlah spesies individu meiofauna pada stasiun A yaitu 34.666 individu $/ \mathrm{m}^{3}$ dari 22 spesies, pada stasiun B yaitu 42.666 individu $/ \mathrm{m}^{3}$ dari 22 spesies dan pada stasiun $C$ yaitu 54.000 individu $\mathrm{m}^{3}$ dari 22 spesies. Uji korelasi pearson didapatkan nilai sebesar 0,565 ( $\geq 0,05$ ) dengan kesimpulan $H_{0}$ diterima dan $H_{1}$ ditolak. Hal ini menunjukkan bahwa tidak ada hubungan antara meiofauna dengan kerapatan lamun yang berbeda di Pulau Panjang Jepara. Nilai korelasi antara meiofauna dengan kerapatan lamun sebesar -0,632, hal ini menunjukkan bahwa tidak adanya hubungan yang erat antara meiofauna dengan kerapatan lamun di Pulau Panjang, Jepara.
\end{abstract}

Kata Kunci : meiofauna, kerapatan lamun, Pulau Panjang.

\begin{abstract}
Seagrass is one of the marine resources that very potential and can be exploited. The benthos organisms such as meiofauna occupies a very important position in the process of biodegradation in coastal ecosystems. This study aims to determine the abundance of meiofauna on different seagrass density in the Beach of Panjang Island, Jepara and to determine the relationship between different seagrass densities to meiofauna abundance. While the sampling method and observations of meiofauna are drawn as samples from 7 points on each station. Meiofauna sampling used pralon that measuring $20 \mathrm{~cm}$ in depth, then the samples were filtered using a sample sieve $0.5 \mathrm{~mm}$ and added as much as $4 \%$ formalin, a solution of rose bengale ${ }^{T M}$ and ludox solution. Pearson correlation test is obtained a value of 0.565 $(\geq 0.05)$ with the conclusion $H_{0}$ is accepted and $H_{1}$ is rejected. This shows that there is no relationship between meiofauna and different seagrass densities in Panjang Island, Jepara. The correlation value between meiofauna and the seagrass density is 0.632 . This indicate that there is no close relationship between meiofauna and seagrass density in the Panjang Island, Jepara.
\end{abstract}

Keywords : meiofauna, seagrass density, Panjang Island.

\section{PENDAHULUAN}

Pulau Panjang merupakan salah satu daerah tujuan wisata di daerah Jepara dan sekitanya. Padang lamun merupakan salah satu ekosistem laut dangkal yang mempunyai peranan penting dalam kehidupan berbagai biota laut serta merupakan salah satu ekosistem bahari yang paling produktif. Salah satu organisme yang dapat terpengaruh oleh penurunan lingkungan sekitar adalah organisme benthos. Menurut Knox (2001), organisme benthos seperti meiofauna menempati posisi yang sangat penting dalam proses biodegradasi di ekosistem pantai. Meiofauna bersifat relatif menetap pada dasar perairan, meiofauna juga dapat dijadikan bioindikator kualitas perairan, karena jika terjadi penurunan kualitas perairan, maka akan mempengaruhi keanekaragaman dan keseragaman dari suatu organisme pada suatu daerah.

Lamun adalah tumbuhan berbunga yang sepenuhnya sudah menyesuaikan diri untuk hidup terbenam di dalam laut. Menurut Alongi (1998), beberapa faktor yang mempengaruhi kehidupan lamun adalah suhu, cahaya, salinitas, kedalaman, substrat dasar perairan dan pergerakan air laut (ombak, arus dan pasang surut). Lamun tersebar pada sebagian besar perairan pantai dunia, hanya pada beberapa wilayah saja tumbuh-tumbuhan ini tidak ditemukan. Higgins dan Thiel (1988) menyatakan bahwa meiofauna berasal dari bahasa Yunani yang memiliki arti "lebih kecil". Fauna 
yang lebih kecil dari fauna yang telah didefinisikan sebelumnya pada batas ukuran terkecil untuk makrofauna yaitu organisme yang tertahan pada saringan mesh size $1 \mu \mathrm{m}$. Kelimpahan meiofauna dipengaruhi oleh beberapa faktor lingkungan, yaitu faktor lingkungan abiotik dan biotik. Meiofauna juga menempati diatas sedimen, termasuk dalam akar tanaman, lumut, mikroalga, dan dalam berbagai struktur binatang termasuk didalam karang dan dalam tabung cacing (Coull, 1988).

Nilai indeks keseragaman dipengaruhi oleh kelimpahan setiap spesies. Nilai indeks keseragaman jenis (e) berkisar antara 0-1. Jika nilai tersebut semakin kecil maka semakin rendah pula kesamaan jenis dalam komunitas tersebut. Sebaliknya semakin besar nilai keseragamannya, maka menunjukkannya kesamaan jenis yang besar atau kelimpahan setiap spesies relatif seimbang. yang berarti kelimpahan relatif dari setiap jenis dapat dikatakan sama dengan kecenderungan didominasi oleh jenis tertentu kecil (Wilhm dan Dorris, 1968). Secara fisiologis adalah faktor-faktor yang membatasi proses fotosintesa, yaitu penetrasi cahaya matahari, unsur hara dan difusi anorganik karbon. Selain itu faktor lain seperti suhu air, salinitas, pergerakan air.

\section{MATERI DAN METODE}

Materi yang digunakan dalam penelitian ini adalah meiofauna dan lamun. Metode yang digunakan adalah metode observasi, yaitu metode yang dilakukan dengan pengamatan dan pencatatan secara sistematis mengenai kejadiankejadian yang diselidiki dalam suatu penelitian dan hasilnya menggambarkan sifat populasi dari objek penelitian. Sampling lamun dilakukan dengan menggunakan metode pemetaan kerapatan lamun. Daerah padang lamun tersebut dibagi menjadi tiga stasiun dengan luasan yang sama $(5 \mathrm{~m}$ x $5 \mathrm{~m})$. Petak contoh yang digunakan berupa alat kuadrat yang berukuran $1 \mathrm{~m}$ x $1 \mathrm{~m}$. Pembagian titik sampel kerapatan lamun yaitu kerapatan jarang (stasiun A) jumlah individu dibawah 106 tegakan $/ \mathrm{m}^{2}$, kerapatan sedang (stasiun B) jumlah individu berkisar antara $107-244$ tegakan $/ \mathrm{m}^{2}$ dan kerapatan padat (stasiun C) jumlah individu diatas 355 tegakan $/ \mathrm{m}^{2}$. Pengambilan sampel dilakukan sebanyak $3 \mathrm{kali}$ ulangan dengan interval waktu berdasarkan surut terendah dari pasang surut air laut.

Pengambilan sampel meiofauna dilakukan dengan menggunakan pralon yang berukuran panjang=20cm dan berdiameter $=5 \mathrm{~cm}$. kemudian menekan pralon tersebut sampai masuk kedalam tanah sedalam $\pm 10 \mathrm{~cm}$ kedalam tanah. Sampel sedimen yang didapat kemudian dimasukkan kedalam saringan sampel dengan ukuran mesh size $0,5 \mathrm{~mm}$. kemudian sampel sedimen yang lolos dari saringan tersebut di masukkan kedalam botol sampel dan di awetkan dengan menggunakan larutan formalin sebanyak 4\% dan diberi rose bengale 2-3 tetes untuk memudahkan dalam menyortir. Sampel selanjutnya di bawa ke laboratorium kemudian diberi larutan ludox.

\section{HASII}

a. Kelimpahan dan Komposisi Lamun

Hasil pengamatan kelimpahan dan komposisi lamun disajikan pada Tabel 1 dibawah ini.

Tabel 1. Kelimpahan dan komposisi lamun

\begin{tabular}{|c|c|c|c|c|c|c|c|}
\hline \multirow{2}{*}{ No } & \multirow{2}{*}{ Spesies } & \multicolumn{2}{|c|}{ A } & \multicolumn{2}{|c|}{$\mathrm{B}$} & \multicolumn{2}{|c|}{$\mathrm{C}$} \\
\hline & & $\mathrm{Ni}$ & $\mathrm{KR}(\%)$ & $\mathrm{ni}$ & $\mathrm{KR}(\%)$ & ni & $\mathrm{KR}(\%)$ \\
\hline 1. & Thalassia $\mathrm{sp}$ & 10965 & 68,86 & 26965 & 73,78 & 31052 & 58,39 \\
\hline 2. & Cymodocea $\mathrm{sp}$ & 1942 & 12,19 & 1697 & 4,64 & 15948 & 29,99 \\
\hline 3. & Enhalus sp & 724 & 4,55 & 2634 & 7,21 & 3086 & 5,80 \\
\hline 4. & Syringodium sp & 986 & 6,20 & 1839 & 5,03 & 1990 & 3,74 \\
\hline \multirow[t]{3}{*}{5.} & Halodule sp & 1306 & 8,20 & 3411 & 9,34 & 1106 & 2,08 \\
\hline & Jumlah & $\begin{array}{c}1.5923 \\
\text { ind } / 150 \mathrm{~m}^{2}\end{array}$ & 100 & $\begin{array}{c}3.6546 \\
\text { ind } / 150 \mathrm{~m}^{2}\end{array}$ & 100 & $\begin{array}{c}5.3182 \\
\text { ind } / 150 \mathrm{~m}^{2}\end{array}$ & 100 \\
\hline & $\sum$ & $106 / \mathrm{m}^{2}$ & & $244 / \mathrm{m}^{2}$ & & $355 / \mathrm{m}^{2}$ & \\
\hline
\end{tabular}

Didapatkan 5 spesies lamun yaitu Thalassia sp, Cymodocea sp, Enhalus sp, Syringodium sp dan Halodule sp. Berdasarkan Tabel 2 di atas, didapatkan diagram histogram dari jenis individu lamun yang disajikan pada gambar 1. 


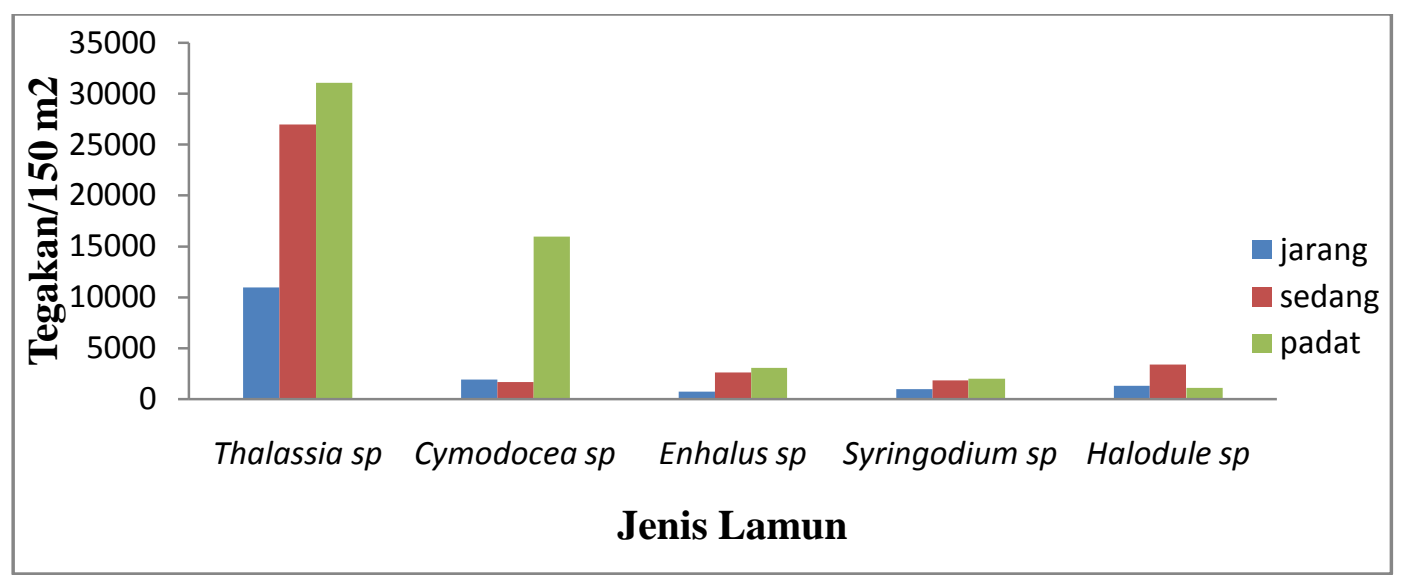

Gambar 1. Jumlah individu lamun di lokasi penelitian Pulau Panjang, Jepara

Berdasarkan Tabel 1 dan histogram diatas dapat diketahui pada titik sampling stasiun A diperoleh hasil yaitu Thalassia sp merupakan spesies yang berjumlah paling banyak yaitu 10965 individu/150m ${ }^{2}$, sedangkan Enhalus sp merupakan jenis yang paling sedikit yaitu 724 individu/150 $\mathrm{m}^{2}$. Pada titik sampling stasiun B diperoleh hasil Thalassia $\mathrm{sp}$ merupakan spesies yang berjumlah paling banyak yaitu 26965 individu $/ 150 \mathrm{~m}^{2}$, sedangkan Cymodoceae sp merupakan spesies yang paling sedikit yaitu berjumlah 1697 individu/150m². Pada titik sampling lamun stasiun $\mathrm{C}$ Thalassia sp merupakan spesies yang berjumlah paling banyak yaitu 31052 individu/150m ${ }^{2}$, sedangkan Holodule sp merupakan jenis yang paling sedikit dijumpai yaitu berjumlah 1106 individu $/ 150 \mathrm{~m}^{2}$.

\section{b. Indeks Keanekaragaman (H') dan Indeks Keseragaman (e) lamun}

Hasil perhitungan Indeks Keanekaragaman (H') dan Indeks Keseragaman (e) dapat dilihat pada Tabel 2.

Tabel 2. Indeks Keanekaragaman (H') dan Indeks Keseragaman (e) lamun

\begin{tabular}{lccc}
\hline \multicolumn{1}{c}{ Keterangan } & A & B & C \\
\hline Indeks Keanekaragaman $\left(\mathrm{H}^{\prime}\right)$ & 1,03 & 0,93 & 1,04 \\
Indeks Keseragaman (e) & 0,64 & 0,58 & 0,65 \\
\hline
\end{tabular}

Dari Tabel 2 diatas dapat dilihat nilai Indeks Keanekaragaman (H') pada stasiun A yaitu 1,03 dengan nilai Indeks Keseragaman (e) yaitu 0,64. Nilai Indeks Keanekaragaman (H') pada stasiun B yaitu 0,93dengan nilai Indeks Keseragaman (e) yaitu 0,58 dan nilai Indeks Keanekaragaman (H') pada stasiun $\mathrm{C}$ yaitu 1,04 dengan nilai Indeks Keseragaman (e) yaitu 0,65.

\section{c. Kelimpahan Meiofauna}

Berdasarkan hasil yang diperoleh didapatkan diagram histogram meiofauna yang tersaji pada gambar di bawah ini.

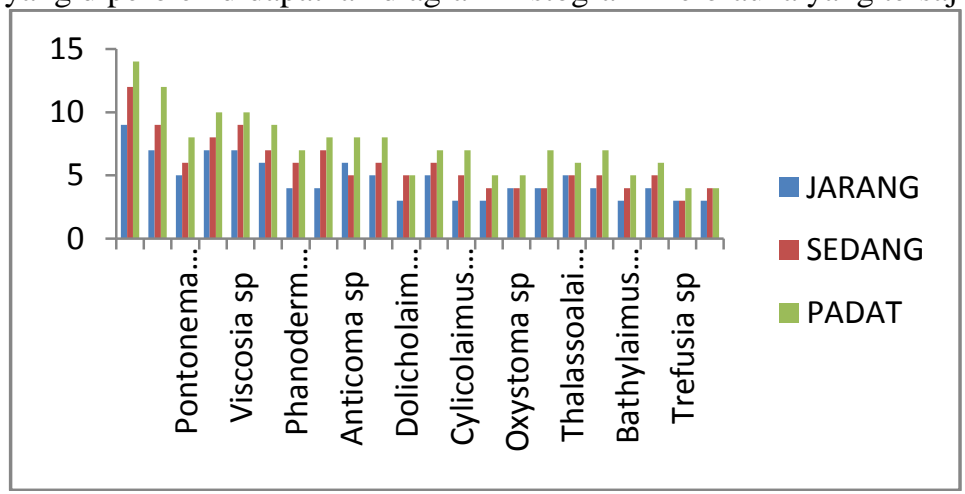

Gambar 2. Jenis Meiofauna yang Ditemukan di Lokasi Penelitian di Pulau Panjang Jepara.

Berdasarkan diagram histogram diatas dapat dilihat bahwa jumlah meiofauna yang paling banyak ditemukan adalah pada stasiun C yaitu 54.000 individu $/ \mathrm{m}^{3}$ dari 22 spesies, sedangkan meiofauna yang paling sedikit ditemukan adalah pada stasiun A yaitu 34.666 individu $/ \mathrm{m}^{3}$ dari 22 spesies. Jumlah meiofauna yang ditemukan pada stasiun B yaitu 42.666 individu $/ \mathrm{m}^{3}$ dari 22 spesies. 


\section{d. Subtrat perairan}

Substrat yang diamati pada saat pengamatan meliputi fraksi substrat, yang meliputi Gravel, pasir, Silt (lanau) dan Clay (lempung). Hasil pengukuran yang diperoleh dapat dilihat pada Tabel 3.

Tabel 3. Substrat perairan

\begin{tabular}{ccccccc}
\hline No & Kerapatan & Gravel (\%) & Pasir (\%) & Silt (Lanau) (\%) & Clay (Lempung) (\%) & Tipe Substrat \\
\hline 1 & A & 15,41 & 79,98 & 4,61 & 0,00 & Pasir \\
2 & B & 5,83 & 88,92 & 5,25 & 0,00 & Pasir \\
3 & C & 17,00 & 78,32 & 4,68 & 0,00 & Pasir Berlumpur \\
\hline
\end{tabular}

Berdasarkan Tabel 3 tersebut dapat dilihat pada daerah stasiun A mengandung Gravel 15,41 \% pasir 79,98 \%, Silt 4,61 \% dan tidak mengandung Clay memiliki tipe substrat pasir. Pada daerah stasiun B jumlah Gravel 5,83\%, pasir $88,92 \%$, Silt 5,25 \% dan tidak mengandung Clay memiliki tipe substrat pasir. Daerah stasiun C mengandung Gravel 17,00 \%, pasir 78,32 \%, Silt 4,68 \% dan tidak mengandung Clay memiliki tipe substrat pasir berlumpur.

\section{e. Bahan Organik}

Tabel 4.

Bahan - bahan organik yang terkandung pada substrat dasar perairan tempat lokasi penelitian dapat dilihat pada

Tabel 4. Bahan organik pada substrat dasar perairan

\begin{tabular}{cccl}
\hline No & Stasiun & Bahan Organik \% & Pustaka \\
\hline 1 & A & 3,62 & $3.47-6.35 \%$ \\
& & 3,84 & http://www.scribd.com/doc/48927003/Komunitas- \\
3 & B & 3,99 & Moluska-di-Pantai-Bama \\
\hline
\end{tabular}

Berdasarkan Tabel 4 didapat kandungan bahan organik di daerah stasiun A sebesar 3,62 \% dan pada stasiun B sebesar 3,84\%, sedangkan 3,99\% pada stasiun C.

\section{f. Parameter Fisika dan Kimia Perairan}

Pengukuran parameter fisika dan kimia dilakukan pada saat sampling dengan hasil pengukuran yang didapatkan seperti pada Tabel 5 .

Tabel 5. Parameter fisika dan kimia perairan

\begin{tabular}{|c|c|c|c|c|c|}
\hline \multirow{2}{*}{ Parameter } & \multirow{2}{*}{ Satuan } & \multicolumn{3}{|c|}{ Hasil Nilai Pengamatan } & \multirow{2}{*}{ Pustaka } \\
\hline & & A & $\mathrm{B}$ & $\mathrm{C}$ & \\
\hline Suhu Air & ${ }^{0} \mathrm{C}$ & $28-30$ & $28-30$ & $28-30$ & $\begin{array}{l}\text { 28-31 (Nontji, } 2002 \text { dalam Ira, } \\
\text { 2011) }\end{array}$ \\
\hline $\mathrm{pH}$ & $\%$ & 8 & 8 & 8 & $\begin{array}{l}\text { 7,8-8,2 (Phillips dan Menez, } 1988 \\
\text { dalam Efriyeldi, 2003) }\end{array}$ \\
\hline Salinitas & $\mathrm{cm}$ & 35 & 35 & 35 & $\begin{array}{l}25-35 \% \text { oo (Zieman, } 1975 \text { dalam } \\
\text { Supriharyono, 2009) }\end{array}$ \\
\hline Kedalaman & $\mathrm{m}$ & $45-60$ & $50-70$ & $55-80$ & $<1000$ (Dahuri et. al, 2001) \\
\hline Kecerahan & - & - & - & - & \\
\hline Kec. Arus & $\mathrm{cm} /$ detik & $0,32-0,38$ & $0,45-0,51$ & $0,56-0,62$ & 0,5 m/s ( Dahuri, 2003) \\
\hline DO & $\mathrm{mg} / \mathrm{liter}$ & $3,0-4,05$ & $3,05-4,15$ & $3,0-4,05$ & $3,5-4,0$ (Hutabarat, 2000) \\
\hline
\end{tabular}

Berdasarkan Tabel 5 tersebut dapat dilihat suhu pada daerah stasiun A, B, dan $\mathrm{C}$ berkisar antara $28-30^{\circ} \mathrm{C}$, pH berkisar antara 7-8, untuk salinitas berkisar antara $25-35 \%$, untuk kedalaman berkisar antar $45-80 \mathrm{~cm}$, sedangkan untuk kecerahan pada ke tiga lokesi tersebut tidak terhingga (dasar perairan terlihat), dan untuk kecepatan arus pada stasiun A berkisar antara 0, $32-0,38 \mathrm{~cm} /$ detik, serta oksigen terlarut (DO) berkisar antara 3,0-4,05 mg/l. Sedangkan daerah stasiun B berkisar antara $0,45-0,51 \mathrm{~cm} /$ detik serta oksegen terlarut (DO) $3,05-4,15 \mathrm{mg} / \mathrm{l}$ dan pada stasiun C kecepatan arus 0,56-0,62 cm/detik serta oksigen terlarut (DO) 3,0-4,05 mg/l.

\section{g. Hubungan Kelimpahan meiofauna dengan Kerapatan Lamun yang Berbeda}

Pada Uji Korelasi Person didapatkan nilai sebesar 0,565 (> 0,05) dengan asumsi $\mathrm{H}_{1}$ diterima dan $\mathrm{H}_{0}$ ditolak. Hal ini menunjukkan bahwa tidak adanya hubungan antara kelimpahan meiofauna dengan kerapatan lamun yang berbeda di Pulau Panjang, Jepara. Nilai korelasi antara kelimpahan meiofauna dengan kerapatan lamun yang berbeda di Pantai Pulai Panjang, Jepara sebesar -0, 634 yang menunjukkan bahwa tidak adanya hubungan yang erat antara kelimpahan meiofauna dengan kerapatan lamun yang berbeda di Pantai Pulau Panjang, Jepara. 


\section{PEMBAHASAN}

Jumlah individu lamun pada stasiun A yaitu dibawah 106 individu/ $150 \mathrm{~m}^{2}$, pada stasiun B jumlah individu lamun yaitu berkisar antara $107-244$ individu $/ 150 \mathrm{~m}^{2}$ dan pada stasiun $\mathrm{C}$ jumlah individu lamun yaitu diatas 355 individu $/ 150 \mathrm{~m}^{2}$ individu $/ 150 \mathrm{~m}^{2}$. Jenis lamun yang banyak ditemukan adalah Thalassia sp dan Cymodocea sp yaitu pada daerah padang lamun alami. Lamun jenis Thalassia sp termasuk spesies yang jumlahnya bisa berlimpah serta memiliki penyebaran yang luas (Dahuri, 2003).Hal ini dikarenakan spesies Thalassia sp biasa hidup dalam semua jenis substrat yang bervariasi dari pecahan karang hingga substrat lunak bahkan pada lumpur cair, tetapi lebih dominan hanya pada substrat keras dan dapat membentuk komunitas tunggal pada pasir kasar (Nienhuis et. al.. 1991 dalam Fauziyah, 2004). Pada lokasi penelitian jenis lamun Syringodium sp dan Halodule sp jarang ditemukan karena lokasi tersebut memiliki substrat dasar berupa pasir kasar dan pecahan karang cangkang molusca sehingga substrat di lokasi penelitian yang berupa butiran pasir kasar diduga dapat mempengaruhi sebaran lamun didaerah tersebut Den Hartog (1970) dalam Fauziyah (2004).

Rendahnya nilai Indeks Keanekaragaman (H') lamun pada tingkat kerapatan yang berbeda dengan nilai 1,03 pada stasiun A, pada stasiun B yaitu 0,93 dan pada stasiun C yaitu 1,04. Berdasarkan dari hasil indeks keanakaragaman tersebut menunjukkan bahwa nilai keanekaragaman lamun pada stasiun A termasuk dalam kategori keanekaragaman sedang, pada stasiun B termasuk dalam kategori keanekaragaman rendah dan pada stasiun C termasuk dalam kategori keanekaragaman sedang. Berdasarkan nilai keanekaragaman tersebut, maka kondisi lingkungan pada daerah stasiun B dapat dikatakan tidak stabil, ketidak stabilannya daerah ini lebih dikarenakan oleh kegiatan manusia disekitar daerah tersebut yaitu dekatnya dengan dermaga tempat kapal wisatawan berkunjung ke Pulau Panjang tersebut, sedangkan pada daerah stasiun $\mathrm{C}$ dan stasiun A dapat dikatakan kurang stabil, karena di sekitar daerah tersebut digunakan sebagai kegiatan nelayan. Nilai indeks keseragaman (e) pada stasiun A sebesar 0,64, pada stasiun B sebesar 0,58dan pada stasiun $\mathrm{C}$ sebesar 0,65 . Hal ini menandakan bahwa pada lokasi tersebut tidak ada jenis lamun yang mendominasi artinya seluruh spesies lamun dapat hidup baik secara seragam atau bersamaan.

Jumlah spesies individu yang paling banyak ditemukan pada daerah lamun stasiun C yaitu 54.000 individu/ $\mathrm{m}^{3}$ sedangkan pada stasiun B yaitu 42.666 individu $/ \mathrm{m}^{3}$ dan pada stasiun A yaitu 34.666 individu $/ \mathrm{m}^{3}$. Hal ini disebabkan karena kepadatan lamun yang tinggi memberikan ketersedian sebagai sumber makanan dan tempat berlindung bagi meiofauna. Ketersedian makanan lamun menghasilkan detritus yang berasal dari serasah daun - daun lamun yang telah membusuk, pernyataan ini sesuai dengan kebiasaan makan meiofauna yaitu deposit feeder (Kikuchi, 1980). Kerapatan lamun yang rendah memberikan perlindungan yang kurang bagi kehidupan meiofauna karena kemampuan untuk menenangkan perairan dari arus dan gelombang kecil. Pada stasiun C ditemukan sedikit lamun disebabkan karena tidak dapat memberikan perlindungan bagi meiofauna dari arus dan gelombang serta tidak memberikan ketersediaan makanan yang cukup. Hal ini di perkuat dengan pernyataan Romimohtarto dan Juana (2001) mengatakan penyesuaian morfologi lamun dilakukan dengan berbagai bentuk misalnya daun yang seperti rumput, lentur dan system akar rimpang yang meluas mampu bertahan terhadap pengaruh ombak, pasang - surut dan perpindahan sedimen di habitat pantai yang dangkal.

Pada daerah stasiun A mengandung Gravel 15,41\%, pasir 79,98 \%, Silt 4,61\% dan tidak mengandung Clay memiliki tipe substrat pasir. Pada daerah stasiun B jumlah Gravel 5,83\%, pasir 88,92\%, Silt 5,25\% dan tidak mengandung Clay memiliki tipe substrat pasir berlumpur. Daerah stasiun C mengandung Gravel 17,00\%, pasir 78,32 $\%$, Silt 4,68 \% dan tidak mengandung Clay memiliki tipe substrat pasir berlumpur. Tipe substrat dasar perairan pantai Pulau Panjang, Jepara adalah pasir. Hasil ini mengacu pada segitiga Miller berdasarkan perbandingan komposisi fraksi pasir, debu dan liat dari masing-masing stasiun. Perbedaan komposisi substrat akan berpengaruh pada jenis lamun yang tumbuh diatasnya. Nybakken (1992), juga menyatakan semua tipe substrat dihuni oleh tumbuhan lamun mulai dari lumpur halus sampai batu-batuan, tetapi lamun yang paling luas dijumpai pada substrat yang lunak.

Hasil bahan organik di daerah stasiun A sebesar 3,62 \% dan pada stasiun B sebesar 3,84 \%, sedangkan 3,99\% pada stasiun C. Kandungan total bahan organik (BOT) di ke 3 daerah kerapatan lamun tidak menunjukkan perbedaan yang signifikan. Lamun dapat hidup di daerah yang kaya maupun yang miskin bahan organik. ada perbedaan morfologi antara lamun yang hidup di daerah yang kaya dengan yang miskin bahan organik. menurut Wicks et al. (2009) dalam Ira (2011) bahwa lamun yang hidup di sedimen yang kaya bahan organik cenderung lebih mudah terlepas dari substrat dibandingkan dengan lamun yang hidup di sedimen pasir yang miskin bahan organik. Lamun yang tumbuh di sedimen miskin organik secara signifikan memiliki daun yang pendek dan sempit dibandingkan dengan yang hidup di sedimen yang kaya bahan organik (Lee dan Dunton 2000 dalam Ira (2011).

Hasil pengukuran parameter fisika dan kimia pada lokasi sampling didapatkan kisaran suhu air pada setiap stasiun yaitu $28^{\circ} \mathrm{C}-30^{\circ} \mathrm{C}$ kisaran nilai tersebut masih berada dalam kisaran nilai toleransi untuk meiofauna, dibuktikan dengan kelimpahan spesies yang relatif sama pada suhu rendah maupun tinggi. Kisaran suhu tersebut masih dalam batas yang layak untuk kehidupan meiofauna karena pada umumnya populasi benthos invertebrata tahan hingga $30^{\circ} \mathrm{C}$ (Hawkes, 1978). Hasil pengukuran salinitas di lokasi sampling, salinitas berada pada kisaran nilai optimum yaitu $29 \%$ - 30\%o. Nilai salinitas pada lokasi penelitian dapat dipengaruhi oleh faktor - faktor penguapan pada permukaan perairan. Keberadaan meiofauna pada setiap stasiun dapat beradaptasi terhadap nilai salinitas yang tinggi yang dilakukan dengan cara mengubah cairan tubuhnya sesuai dengan konsentrasi garam di luar tubuhnya. Kelarutan oksigen dan gas- gas lain 
juga berkurang dengan meningkatnya salinitas, sehingga kadar oksigen di laut cenderung lebih rendah dibandingkan di perairan tawar. Kisaran nilai salinitas dan suhu pada lokasi sampling termasuk nilai optimum untuk pertumbuhan meiofauna.

Derajat keasaman atau $\mathrm{pH}$ merupakan salah satu faktor yang mempengaruhi kehidupan meiofauna. $\mathrm{pH}$ air pada lokasi sampling tidak bervariasi yaitu 8. Hal ini sesuai dengan pernyataan Odum (1971) yaitu, umumnya derajat keasaman atau $\mathrm{pH}$ perairan berkisar antara $4-9$ masih layak untuk kehidupan biota air termasuk meiofauna karena $\mathrm{pH}$ berperan dalam pengaturan respirasi dan sistem enzim. Fluktuasi $\mathrm{pH}$ dipengaruhi oleh fotosintesa dan dekomposisi bahan organik.

Kecepatan arus di lokasi sampling berkisar antara 0,32-0,62 cm/detik. Dari hasil yang diperoleh menunjukkan adanya hubungan antara kecepatan arus dengan kerapatan lamun. Kecepatan arus pada setiap stasiun cukup bervariasi yaitu pada stasiun A $0,32-0,38 \mathrm{~cm} /$ detik, pada stasiun B $0,45-0,51 \mathrm{~cm} /$ detik dan pada stasiun $\mathrm{C} 0,56-0,62 \mathrm{~cm} /$ detik. Pada stasiun $\mathrm{C}$ kecepatan arus sangat besar sehingga sangat mempengaruhi kehidupan meiofauna karena dengan gerakan ombak akan menambah oksigen dalam air dan banyaknya ketersedian bahan makanan untuk kehidupan meiofauna. Kedalaman lokasi sampling hampir seragam yaitu $45-80 \mathrm{~cm}$. Kedalaman berhubungan dengan kecerahan suatu perairan, lamun dapat tumbuh optimum pada kedalaman sampai dengan 20m (Alongi, 1998).

Hasil pengukuran DO di lokasi sampling yaitu 3,0 - 4,15 mg/l. Menurut Hutabarat (2000), kisaran DO yang ada pada susatu perairan berkisar antara 3,5-6 mg/l, sehingga dapat dikatakan bahwa kisaran DO pada stasiun penelitian masih cukup layak bagi kehidupan organisme di perairan. Hasil pengukuran parameter fisika kimia, substrat dasar yang didapatkan pada stasiun A, B dan C berbeda, pada stasiun A dan stasiun B substrat dasar pasir dan pada stasiun C substrat dasar pasir berlumpur.

Hasil analisa uji korelasi pearson didapatkan nilai sebesar 0,565 ( $\geq 0,05)$, dengan kesimpulan $\mathrm{H}_{0}$ diterima dan $\mathrm{H}_{1}$ ditolak yaitu tidak ada hubungan antara kelimpahan meiofauna pada kerapatan lamun yang berbeda di pulau Panjang Jepara. Selain itu, didapatkan nilai korelasi antara kelimpahan meiofauna dengan kerapatan lamun sebesar -0,632. Hasil ini menunjukkan tidak adanya hubungan yang erat antara kelimpahan meiofauna dengan kerapatan lamun di Pulau Panjang. Berdasarkan hal ini dapat disimpulkan bahwa kerapatan lamun yang berbeda tidak terlalu berpengaruh terhadap meiofauna yang ada di peraiaran pantai Pulau Panjang Jepara, karena keduanya tidak berhubungan erat.

\section{KESIMPULAN}

Berdasarkan hasil penelitian yang diperoleh, bahwa kelimpahan meiofauna yang ditemukan pada stasiun A yaitu 34.666 individu $/ \mathrm{m}^{3}$, pada stasiun B yaitu 42.666 individu $/ \mathrm{m}^{3}$ dan pada stasiun $C$ yaitu 54.000 individu $/ \mathrm{m}^{3}$.

Dari hasil Uji Korelasi Person menunjukkan bahwa tidak adanya hubungan yang erat antara kerapatan lamun dengan kelimpahan meiofauna di Pantai Pulau Panjang, Jepara.

\section{SARAN}

Perlu diadakannya penelitian lebih lanjut mengenai hubungan antara kerapatan lamun dengan kelimpahan meiofauna pada waktu dan musim yang berbeda. Hal ini dimaksudkan untuk mengetahui kondisi lamun di Pulau Panjang Jepara pada setiap musimnya dan dapat digunakan untuk pedoman pengelolaan yang berkelanjutan.

\section{Ucapan Terimakasih}

Pada kesempatan ini penulis mengucapkan banyak terimakasih kepada Ir. Ruswahyuni, MS.c. dan Dra. Niniek Widyorini, MS. yang telah membimbing dan membantu dalam penyusunan penulisan ini, serta keluarga dan temanteman yang turut berpartisipasi dalam penelitian dan terus memberikan dukungan.

\section{DAFTAR PUSTAKA}

Alongi, D.M, 1998. Coastal Ecosystem Proces. CRC. Press. New York.

Coull, B.C. 1988. Ecology of The Marine Meiofauna. Smithsonian Institution Press. Washington DC.

Dahuri, R. 2003. Keanekaragaman Hayati Laut - Aset Pembangunan Berkelanjutan. Jakarta. Pt. Gramedia Pustaka Utama. Jakarta

Dahuri,R Rais, S.P Ginting dan M.J Sitepu.2004. Pengelolaan Sumberdaya Wilayah Pesisir dan Lautan Secara Terpadu. Pradnya Paramita, Jakarta. 328 hal

Fauziyah M. I. 2004. Struktur Komunitas Padang Lamun di Pantai Batu Jimbar Sanur. Skripsi. Fakultas Perikanan dan Ilmu Kelautan, Institut Pertanian Bogor. Bogor. 60 hal

Hawkes, A. 1978. Invertebrate as Indicator of river Water Quality. In: A. James and L. Evinson (Eds). Biological Indocators of Water Qualiti John Wiley and Sons. Toronto.

Higgins, R.P. dan Thiel, H. 1988. Introduction to The Study of Meiofauna. Smithsonian Institution Press. Washington DC

Hutabarat, S. 2000. Peran Kondisi Oseanografis Terhadap Perubahan Iklim, Produktivitas,dan Distribusi Biota Laut. Universitas Diponegoro. Semarang.34 hlm. 
Ira. 2011. Keterkaitan Padang Lamun Sebagai Perangkap dan Penghasil Bahan Organik Dengan Struktur Komunitas Makrozoobenthos Di Perairan Pulau Barrang Lompo. Tesis. Institut Pertanian Bogor.

Kikuchi, T. 1980. Fauna Relationship in Temperate Seagrass Bed in Hand Book of Seagrass Biological : An Ecosystem Perspective. Philips R.C. Mc. Roy (ed) Garland STPM - Press, New York.

Knox, G.A. 2001. The Ecology of Seashores. CRC Press. London.

Nontji, A. 1987. Laut Nusantara. Djambanan. Jakarta. 368 hlm.

Nybakken, J. W. 1992. Biologi Laut, Suatu Pendekatan Ekologis. Gramedia. Jakarta.

Odum, E.P. 1971. Fundamental of Ecology. WB Sounders Company, Philadelpia. 574 pp.

Romimohtarto, K dan S. Juwana. 2001. Biologi Laut, Ilmu Pengetahuan tentang Biota Laut. Jakarta: Djambatan.

Wilhm, J. dan Dorris. 1968. Biological Parameter for Water Quality Criteria. Bio Science 